\title{
A Aquisição da Propriedade em Garantia.
}

(Sua defesa judiciária)

\author{
Félix Ruiz Alonso
}

\author{
SUMÁRIO \\ I - PARTE \\ DIREITO SUBSTANTIVO
}

1. Alienação fiảuciária em garantia. - 2. As inovações da alienação fiduciária. - 3. Aquisição do domínio sem a tradição. - 4. A propriedade sem a posse. - 5. Uma criação da lei.

$$
\text { II - PARTE }
$$

DIREITO PROCESSUAL

6. O devedor depositário. - 7. Responsabilidades do devedor. - 8. O inadimplemento. - 9. A ação de depósito.

- 10. As ações possessórias. - 11. A ação da reserva de domínio.

$$
\begin{aligned}
& \text { III - PARTE } \\
& \text { CONCLUSÕES }
\end{aligned}
$$

\section{I n t r od u çã o.}

O título dêste ensaio, "A Aquisição da Propriedade em Garantia", parecerá estranho. Não obstante, à medida que mais nos familiarizarmos com o nôvo instituto de "Alienação Fiduciảria em Garantia", cada vez mais nos parecerá 
que estamos perante uma nova modalidade de propriedade, expressamente criada para servir de garantia ao credor, e que muito bem poderia ser chamada "Propriedade de garantia". O credor fiduciário adquire essa propriedade; por isso intitulamos êste ensaio "A Aquisição da Propriedade em Garantia (Sua Defesa Judiciária)", que corresponde com a "Alienação Fiduciária em Garantia" que efetua o devedor a favor do credor, segundo o art. $66 \mathrm{da}$ Lei de Mercado de Capitais (n..$^{\circ}$ 4.728, de 14.7.65).

O ensaio é sucinto, direto, sem nos demorarmos nos lugares por onde obrigatòriamente se passa na sua elaboração linear. Não havendo bibliografia especializada, até o presente, as citações são escassas. É um ensaio feito a partir do artigo 66, combinado com outras normas dos Códigos Civil e de Processo Civil. A finalidade precípua é analisar a parte material do instituto e apontar apenas uma contribuição processual civil, que processualistas poderão desenvolver. Os aspectos processuais penais, propositadamente, não os trataremos.

As normas existentes de direito constituído disciplinando esta matéria são suficientes, independendo de regulamentação. Seria desnecessária qualquer nova ordenação da matéria, - a não ser a título declarativo ou adjetivo - por ser claro o ordenamento que existe.

Também tivemos presentes os trabalhos conhecidos sôbre o assunto: o de Pontes de Miranda ("Tratado de Direito Privado", vol. 52, págs. 339-371, Ed. Borsoi, Rio de Janeiro 1966), Alfredo BuzaId ("Ensaio sôbre a Alienação Fiduciária em Garantia" 13.1.69, Acrefi, São Paulo) e o de Rubens Gomes de Sousa ("O ICM e a Alienação Fiduciária em Garantia", Parecer de 15.5.69, Acrefi, São Paulo); além de nosso trabalho "A Alienação Fiduciária em Garantia" apresentado no $1 .^{\circ}$ ano do Curso de Doutoramento (ano de 1966), publicado na Revista da Faculdade de Direito da U.S.P., vol. 62, de 1967. Todos êles foram levados em consideração. 
1. Convém iniciar lembrando o que seja "alienação fiduciária em garantia" e lembrá-lo segundo o texto legal, já que estamos perante um instituto não só nôvo, mas também algo desconcertante à primeira vista; por isso a autoridade do legislador fará que aceitemos aquilo que, sem ela, nos seria difícil de aceitar.

O art. 66 da Lei de Mercado de Capitais de 1965, diz que "na alienação fiduciária de bem móvel o credor tem o domínio da coisa alienada, até a liquidação da dívida garantida."

0 mesmo artigo, no parágrafo $2^{\circ}$, continua dizendo que “o instrumento de alienação fiduciária transfere o domínio da coisa alienada, independentemente da sua tradição, continuando o devedor a possuí-la em nome do adquirente, segundo as condições do contrato, e com as responsabilidades de depositário".

Ainda, no parágrafo $5 .^{\circ}$ temos outros elementos indispensáveis para a boa compreensão da nova garantia. Reza assim: "No caso de inadimplemento da obrigação garantida, o proprietário pode vender a coisa a terceiros e aplicar o preço da venda no pagamento do seu crédito e das despesas decorrentes da cobrança, entregando ao devedor o saldo porventura apurado, se houver."

Estamos, assim, perante um contrato de garantia, contrato êste acessório que acompanha sempre outra obrigação principal. Suponhamos que Gáio devesse a Ulpiano, como conseqüência de um empréstimo, a importância de mil moedas, e que êsse empréstimo estivesse garantido pela alienação fiduciária de um veículo, por exemplo, que Gáio tivesse realizado em favor de Ulpiano. A obrigação principal é o empréstimo das mil moedas e o contrato secundário, colateral, é o da "Alienação Fiduciária em Garantia."

Note-se, que o credor não é apenas credor, mas foi elevado à categoria suprema de proprietário. É o "dominus", o proprietário fiduciário, o adquirente - como é designado em diferentes lugares do mencionado art. 66. 
Paralelamente o devedor é depositário, é alienante, possui em nome do adquirente, segundo dispõe o mesmo art. 66 .

Aparece, assim, configurando a alienação fiduciária, mais um instituto, o do depósito, de forma que o legislador, na nova garantia, combina a propriedade e o depósito, dando ao credor o título de proprietário e ao devedor o de depositário.

Como é lógico, se a lei recorre a essa configuração fá-lo por alguma razão. O legislador não legisla arbitràriamente.

Dissemos em trabalho anterior ${ }^{1}$, que a alienação fiduciária, pelo fato de entrecruzar duas relações, uma principal - o mútuo - e outra secundária, translatícia de propriedade, pertencia originàriamente ao gênero dos negócios fiduciários. Não obstante isso, dizíamos, o legislador codificou essa combinação fiduciária, destacando-a do gênero dos negócios fiduciários a que pertence, criando uma espécie típica, com forma legal própria. "Genus per speciem differtur" O gênero (negócio fiduciário) se diferencia em suas espécies: alienação fiduciária em garantia².

2. Era de esperar que a nova garantia custasse ser compreendida. Certamente, a nova garantia é uma construção complexa do legislador e introduz algumas novidades, que exigem um estudo apurado.

Antes de mais nada, o nôvo instituto além de outras novidades, tem as seguintes:

1. ${ }^{\text {) }}$ O credor, não é apenas credor, mas é proprietário do objeto que o devedor lhe transfere em garantia.

1. "A Alienação Fiduciária em Garantia", Rev. da Faculdade de Direito da U.S.P., vol 62, 1967, págs. 422 e seguintes.

2. Faz-se esta observação porque estudiosos do assunto não se aperceberam de que a alienação fiduciária não pode mais ser tratada como simples negócio fiduciário. o legislador tipificou-a, dando-lhe uma forma legal clara e precisa, que deve-se respeitar. 
obvviamente, o legislador procurou uma garantia mais forte, superior às tradicionais.

Se se cria um instituto nôvo, lògicamente, é para introduzir alguma novidade, alguma melhoria e, em se tratando de garantias, para dar uma proteção melhor ao garantido, ao credor - já que esta é a finalidade de tôda garantia.

No caso, o legislador eleva o credor à categoria de proprietário, mas isto o faz para que possa usufruir das vantagens decorrentes desta posição. Não se compreenderia que o credor fôsse proprietário e que, à hora de defender seus direitos, estivesse menos protegido do que em qualquer outra das demais garantias até aqui existentes: penhor, hipoteca ou anticrese.

A jurisprudência dará a última palavra com uma proteção à altura. Se o legislador criou uma garantia nova, forçando até os institutos tradicionais de que se servira na sua construção, não o fez afinal, para obter mais uma garantia, inferior ou igual às outras. A jurisprudência seguirá o rumo do legislador, levará ao seu têrmo o labor por êle iniciado, interpretará fielmente a "mens legislatoris."

2. $\left.{ }^{a}\right)$ o credor adquire o domínio duma coisa móvel, sem a tradição. E uma regra geral do nosso direito a necessidade da tradição. $O$ art. 620 do nosso Código Civil, estabelece o critério geral da aquisição de coisas móveis: " $O$ domínio das coisas não se transfere pelos contratos antes da tradição. Mas esta se subentende, quando o transmitente continua a possuir pelo constituto possessório."

Ainda o art. 675 insiste em que: "Os direitos reais sôbre coisas móveis, quando constituídos, ou transmitidos por atos entre vivos, só se adquirem com a tradição."

No caso da alienação fiduciária, temos uma exceção à regra geral. $\mathrm{O}$ art. $66, \S 2 .^{\circ} \mathrm{diz}$ taxativamente, que o credor adquire o domínio da coisa alienada, "independentemente da sua tradição", continuando o devedor na posse do objeto. 
Se a intenção do legislador foi transferir o domínio sem a tradição, então também não há porque subentender a tradição, nem porque falar em constituto possessório. Não há constituto possessório, porque êle está sempre subordinado à tradição. Onde não deve haver tradição não se pode subentendê-la; só se pode subentendê-la onde deve haver tradição.

Estamos perante uma nova modalidade de aquisição de propriedade móvel: se transfere pelo contrato, sem tradição. "O instrumento da alienação fiduciária transfere o domínio da coisa alienada".

Do exposto, se conclui que aquela regra geral, exigindo a tradição, no caso foi derrogada.

3. $\left.{ }^{2}\right)$ Transfere-se o domínio, transferindo só o título do domínio. A maior inovação talvez esteja precisamente nesta conquista do direito brasileiro, diretamente relacionada à transferência sem a tradição. Isto implicou em separar, por um lado, a "titularidade" da propriedade dos direitos inerentes a ela, para em seguida, e por outro lado, transferir êsse título vazio de conteúdo próprio.

É natural que custe compreender o alcance da inovação e queiramos transferir ao adquirente (credor) aquilo que habitualmente adquiria; como podem ser alguns dos direitos decorrentes do título ou pelo menos, a posse chamada indireta.

4. ${ }^{\text {a) } O}$ proprietário não tem posse, nem sequer a indlreta. Observe-se que ordinàriamente, a posse indireta aparece como remanescente ${ }^{3}$ no alienante, após o ato de alie-

3. "Quando, por força de obrigação, ou direito, em casos como o do usufrutuário, do credor pignoratício (o legislador fala do penhor com entrega da coisa ao credor), do locatário, se exerce temporàriamente a posse direta, não anula esta às pessoas, de quem êles a houveram, a posse indireta". Art. 486 do Cód. Civil. Repare-se que a posse indireta deve corresponder ao alienante que é o devedor, êle tem na alienação fiduciária a posse direta. $O$ credor não obteve, em momento algum, a posse do devedor. 
nação. No caso da alienação fiduciária não se produziria dessa forma, já que ninguém pretenderia que o alienante tivesse "posse indireta" - o alienante continua na posse direta - mas sim o adquirente. Mas, como é possivel posse indireta no adquirente? É imprópria dêle. Na verdade o credor adquirente não tem posse indireta, não tem posse alguma.

A posse do devedor é anterior ao credor e continua tôda ela sem solução de continuidade em poder daquêle, após o surgimento do credor-adquirente. O devedor transfere apenas a propriedade, sem posse.

5. $\left.{ }^{2}\right)$ direito potencial do credor-proprietário a dispor da coisa para vendê-la.

No caso de inadimplemento da obrigação principal, por parte do devedor, o proprietário fiduciário poderá vender a coisa, para ressarcir-se.

Nesta hipótese apenas, o "dominus" poderá dispor da coisa. O direito à venda da coisa é o único direito, dentre todos os direitos inerentes ao domínio, que se atualiza, que emerge do titulo. E ainda, se fôr necessário para a venda, renascerá no título concomitantemente o direito a posse - dêste aspecto trataremos depois.

6. ${ }^{\text {a) }}$ O devedor é depositário, por equiparação da lei. Aliás a figura de depositário está perfeitamente desenhada. Diz a lei falando do devedor: que tem as responsabilidades do depositário, que tem posse de coisa alheia, que tem a coisa em nome do adquirente. Maneiras tôdas elas de dentro da laconicidade própria dos textos legais - descrever o estado de depositário, em que o legislador colocou o devedor.

O depósito é uma figura jurídica que pode permitir ao depositário, que tem a posse do objeto, servir-se dêle. Esta característica do depósito fez possível que o legislador o utilizasse, para configurar a alienação fiduciária - fazendo ao devedor um depositário-usuário. 
7.3) O devedor é depositário, com a posse plena.

$\mathrm{O}$ devedor não tem a posse da coisa pelo constituto possessório - como seria fácil concluir em decorrência de situações paralelas -, mas continua na posse da coisa, depois de aliená-la.

"Constituto possessório é a operação jurídica, em virtude da qual, aquêle que possuía em seu próprio nome, passa, em seguida, a possuir em nome de outrem." ${ }_{4}$

À primeira vista pode parecer que o depositário adquiriu a posse pelo constituto. Antes era possuidor "nomine proprio" e, após a alienação, passou a possuir "alieno nomine". Mas esta mudança não se deve a cláusula "constituti".

Foi o legislador quem criou as diferentes situações das partes, tanto do credor proprietário, quanto do devedor depositário, através de equiparações legais — mas não houve constituto possessório ${ }^{5}$, que é sempre uma convenção "inter partes", e que por conseguinte deve constar por escrito. ${ }^{6}$

Além do mais não há necessidade de recorrermos a explicações complexas, quando a lei é clara, ela diz singelamente: "continuando o devedor a possuí-la em nome do adquirente". Não pelo constituto possessório, mas "ex permanentia" De qualquer maneira, tanto se reconhecida pelo preceito legal, como se adquirida pelo constituto possessório - ninguém discutiu a posse do devedor.

4. Clóvis Bevilacqua, "Direito das Coisas", $10^{\circ}$ volume, Rev. Forense, Rio, 1956, pág. 48.

5. No constituto possessório há uma mudança de relação entre o possuidor e o objeto, que passa da posse "nomine proprio" $\mathrm{Y}$ posse "alieno nomire"; antes, por exemplo, um possuidor era proprietário de imóvel, que vende, continuando a morar nêle como inquilino; para salvaguardar o nôvo estado de inquilino e, especìficamente, a posse dêle como tal, obtem-na através do constituto possessório.

$\mathrm{Na}$ alienação fiduciária, também, o alienante pasșa de proprietário a depositário, mas esta mudança - repetimos - tem lugar porque o legislador assim o quiz - não depende da vontade das partes.

6. “A cláusula constituti não se presume". Rev. Trib. 184/744, Rev. Forense 80/157. 
3. Diz o texto legal que "o instrumento da alienação fiduciária transfere o domínio da coisa alienada, independentemente da sua tradição, continuando o devedor a possuí-la em nome do adquirente".

Temos aqui uma nova maneira de aquisição da propriedade móvel - da aquisição da "propriedade fiduciária em garantia" - em que se adquire o domínio sem haver a tradição da coisa.

Para transferir a propriedade, bastaria em principio, alienar a sua titularidade, o justo título - sem que fôsse essencialmente necessária a tradição da coisa. Esta, a "traditio", é uma exigência legal-tradicional, não fundamentalmente necessária, e por conseguinte prescindivel.

Existem várias teorias sôbre os requisitos necessários para transmitir a propriedade móvel. A mais geral é a teoria do "título e modo" ou "título e traditio". Além do título de alienação, - a expressão do "animus", da "intentio" - que é o elemento essencial em todos os direitos, por mais simples e informal que seja, se fala de um segundo elemento, mais ou menos superado històricamente, que é a "traditio", a entrega de fato da coisa cuja propriecade se transfere.

Brevemente, podemos recordar o formalismo romano e a exigência, no período clássico, da "traditio". Éste elemento se conserva ainda bastante, no direito germânico, e também em outros direitos de base romanística, como é o caso do direito brasileiro. O direito francês prescindiu totalmente dessa exigência, em virtude da teoria chamada da transmissão consensual.

A questão na atualidade não tem maior relevância. A teoria do "título e modo", que exigia uma fundamentação da transmissão e um modo, que seria a "traditio", foi ultrapassada. Hoje se espalha a teoria contratualista, segundo a qual só a "vis contractualis" justifica a transferência da propriedade. A "traditio" passou a ser um requisito em vigor apenas em determinados países. 
Poder-se-ia transferir o domínio das coisas móveis sem a tradição delas; bastaria que o legislador o autorizasse. No instituto nôvo da alienação fiduciária, que nos ocupa, o legislador acolheu expressamente a transferência sem a tradição.

Como se transfere o domínio no caso? Qual o título ou formalidade da alienação? A estas perguntas respondem claramente as próprias palavras da lei: "o instrumento da alienação fiduciária transfere o domínio da coisa alienada, independentemente da sua tradição". A doutrina contratualista foi claramente acolhida, no caso.

4. Quando se diz que o proprietário fiduciário tem posse (indireta) pensa-se que a propriedade arrasta a posse necessàriamente consigo. Na verdade, posse e propriedade podem seguir caminhos diferentes, sem interferirem. No caso do fiduciário, só poderíamos reconhecer nêle posse indireta, se o legislador, por ato especial ficticiamente lha atribuísse - o qual seria muito conveniente: reforçaria o proprietário e obteria as ações possessórias.

O legislador, legislando a alienação fiduciária diz, por um lado, que o credor adquire a propriedade fiduciária duma coisa móvel do devedor. Não menciona a posse. Esta é mencionada sòmente no parágrafo $2{ }^{\circ}$, do artigo que nos ocupa, quando diz que o devedor continua na posse đo objeto alienado, que já tinha quando proprietário.

Já ficou provado acima (item $2, \mathrm{n}^{\circ}{ }^{4}$ ) que no proprielário não há posse indireta. Ainda que admitíssemos a hipótese da existência da "traditio" por parte do devedor ao credor, nem assim poderíamos falar em posse indireta do credor, que é o adquirente não o alienante. A posse indireta é própria do alienante, remanesce no alienante, no proprietário originário; não é do adquirente.

A noção de posse indireta se inverteria se aplicada ao credor da alienação fiduciária em garantia.

$O$ posse indireta é um estado passageiro de enfraquecimento da posse, naquêle que era pleno possuidor, em 
decorrência de alienação real. Decorrido êsse periodo, volta à plena posse. Mas o credor-proprietário não era pleno possuidor, antes da alienação fiduciária, e nem sequer o será.

Diz Clóvis Bevilacqua, falando da posse indireta que ela pressupõe: "um possuidor (proprietário ou não) anterior ou originário ... e outro posterior ou derivado"”. No possuidor anterior, após a bipartição da posse, remanesce a posse indireta. O possuidor posterior, adquirente, obtém a posse direta. "Cessando a posse direta ou imediata, o possuidor indireto, ou mediato, reassume a posse plena, se está em condição de exercê-la". 8

5. Ao longo destas linhas se insiste repetidas vêzes no caráter eminentemente jurídico-positivo dêste instituto. Não está o Direito dependendo da intenção de mero credor e de mero devedor que as partes tenham, em decorrência do contrato de mútuo entre elas celebrado. O legislador criou um nôvo instituto de garantia, no qual o credor é proprietário da coisa que a favor dêle aliena em garantia o devedor, e êste é depositário dela. Tudo isto é assim porque o legislador quis. Estamos perante um instituto legal, fruto exclusivo da lei.

E necessário diferenciar as duas esferas, por um lado a do mundo real, natural, e por outro, a esfera jurídica ${ }^{9}$

7 e 8. Clóvis Bevilaaceua, "Direito das Coisas", 1. volume, Rev. Forense, Rio, 1956, pág. 34.

9. Cifuentes, Rafaer Liano: "Naturaleza Jurídica de la Fictio Juris" Estudio General de Navarra, Ed. Rialp S.A., Madrid, 1963, pág. 79. "O Direito positivo surge duma "potestas" que, ressalvadas as exigências de justiça, do Direito Natural, completa - valendo-se dessa soberania - à ordem jurídico-natural" .. "O legislador, por conseguinte, tem poder para outorgar uns efeitos jurídicos a determinados pressupostos de fato que estritamente não fôram contemplados pela norma natural. Estes efeitos jurídicos de Direito positivo não surgem - ex natura rei - por exigências da natureza mesma das coisas, nem sequer naiguns casos nascem como exigências estritas de Direito Natural, senão que são produzidos mais por uma valoração dêsses pressupostos equitativamente feita pelo legislador" 
A nós interessa especialmente esta segunda, com maior razão quando se tratar de valorizar normas ou institutos devidos ao legislador, independentemente de outras realidades.

Quando a norma de determinado país reza que a maioridade se alcança aos vinte e um anos, nada interessa o grau de desenvolvimento intelectual, social ou profissional do jovem. É maior de idade "ex vi legis". No ordenamento jurídico de outros países pode-se decretar a maioridade aos vinte ou vinte e dois anos - o legislador terá as suas razões para isso -- mas ao igual os jovens atingirão a maioridade jurídica nessas idades respectivamente. Essa será a verdade jurídica da qual decorrerão tôda uma série de efeitos. Muitos exemplos poder-se-iam pôr de ficções, equiparações e de presunções legais, que lembrariam a fôrça criativa do dispositivo legal, à margem da realidade natural ${ }^{10}$.

"A alienação fiduciária em garantia é uma figura jurídica típica, criada pela Lei" ${ }^{11}$

O legislador além de outras equiparações, equiparou o devedor ao depositário, e desta equiparação decorrem efeitos e responsabilidades graves para êle. E'm continuação, veremos em primeiro lugar a equiparação, em segundo lugar os seus efeitos, para concluirmos com uma tentativa processual apropriada — depois desta visão sumária do direito material da alienação fiduciária em garantia.

10. SFORZA, C.: O legislador encontra-se limitado principalmente pela existência duma ordem natural anterior e superior a êle. Porisso o Direito não é uma forma absolutamente desvinculada da realidade. "Guida allo studio della Filosofia del Diritto", $3 .^{\mathrm{a}}$ ed., Roma, 1955, pág. 18.

O fato de estarmos salientando o valor dos institutos legais, não significa acolher a Teoria Kelseniana do Direito Puro. Sem chegar a extremos e admitindo os limites naturais e morais da ação legisladora, não resta dúvida a grande margem de criatividade que cabe ao legislador, dentro do seu fim, ordenador, organizador.

11. RUbens Gomes de Sousa, op. cit., pág. 45. 
6. A alienação fiduciária em garantia - e isto está sendo comumente aceito - pertence ao gênero dos negócios fiduciários, embora destacada dêles, uma vez que o legislador institucionalizou uma determinada figura de negócio fiduciário, aquela precisamente, em que:

$\left.1^{\circ}\right)$ Realiza-se um contrato de mútuo entre credor e devedor.

2..$^{\circ}$ O devedor transfere a propriedade de um bem móvel ao credor, que continua em poder do devedor.

Temos aí os dois pactos cruzados característicos de qualquer negócio fiduciário, sendo um dêles translatício da propriedade. A finalidade que se pretende é a garantia do credor. No negócio fiduciário a transferência da propriedade, que é o meio comumente adotado para garantir o credor, excede o fim do negócio em si. O legislador, elevando êste negócio à categoria legal característica - alienação fiduciária em garantia - terá ocasião de polir-lhe as arestas, dando-lhe forma adequada, precisa.

A lei criou, em verdade, uma nova forma de propriedade, limitada, especialmente enfraquecida, a serviço do credor, eliminando assim um dos excessos daquêle negócio fiduciário. 0 devedor aliena essa propriedade especial e o credor a adquire. ${ }^{12}$

Por outro lado o negócio tem o seu acabamento próprio com o depósito, que o credor-depositante faz ao devedor-depositário - embora isto não se realize no plano real-natural, mas no plano jurídico-legal.

12. Provàvelmente, êste instituto poderá vir a ser incluido entre os modos de aquisição da propriedade: a aquisição da propriedade fiduciária em garantia. Igualmente, a propriedade em questão poderse-ia chamar de "propriedade fiduciária em garantia', como subdivisão da propriedade limitada.

Inclui-se entre as garantias apenas em função do fim: a garantia. Mas observe-se que não estamos máis perante um direito real sôbre coisa alheia - "iura in re aliena" A coisa é do credor, que a adquiriu porque o devedor alienou-a em favor dêle. 
"A relação jurídica de depósito não resulta de um contrato, mas de expressa disposição legal. As partes não a escolheram por manifestação contratual de vontade; aceitaram-na a partir do momento em que desejaram concluir o negócio jurídico da alienação fiduciária em garantia. Conseqüentemente, devem sujeitar-se à norma imperativa que lhes regula os direitos e as obrigações". ${ }^{13}$

Não há outra maneira de explicar aquilo que se encerra sob o artigo 66, a não ser essa. Pelo menos é a explicação que se depreende sem violentá-lo.

Aquêle artigo, no seu $\S 2 .^{\circ} \mathrm{diz}$ a respeito da coisa alienada que continua "o devedor a possuí-la em nome do adquirente, segundo as condições do contrato, e com as responsabilidades de depositário".

O devedor não possui mais "nomine proprio", mas em nome de outro: do proprietário. Possuir a coisa em nome de outro é uma característica essencial do contrato de depósito, no qual "recebe o depositário um objeto móvel, para guarda, até que o depositante o reclame" ${ }_{14}$

De resto o contrato de depósito, segundo as nossas leis, desfruta de bastante elasticidade: é contrato unilateral, embora possa ser bilateral; é contrato real, estando sempre a coisa com o depositário; pode-se fixar um prazo de restituição; podendo ainda o depositário, se previsto no contrato, servir-se da coisa depositada ${ }^{15}$. Isto último permitiu ao legislador dizer que o devedor-depositário possuiria a coisa "segundo as condições do contrato". Com efeito, o motivo pelo qual se criou esta nova forma de garantia, foi para o atendimento às necessidades da produção e do comércio, no sentido de deixar a coisa a serviço do devedor, para que a desfrute ou produza com ela.

$\mathrm{O}$ art. 66, finalmente, é taxativo quando diz que o devedor tem "as responsabilidades de depositário". "O depositário é obrigado a ter na guarda e conservação da coisa

13. BuzaId, AlFredo, obra cit., pág. 47.

14. Art. 1.265 do Código Civil.

15. Art. 1.275 do Código Civil. 
depositada o cuidado e diligência que costuma com o que lhe pertence, bem como a restituí-la"...16.

"Seja voluntário ou necessário o depósito, o depositário, que o não restituir, quando exigido, será compelido a fazê-lo mediante prisão não excedente a um ano, e a ressarcir os prejuízos."17.

7. Dessas responsabilidades não se pode fugir, sob pena de enfraquecermos o instituto. O legislador sabia muito bem, quando se servia do depósito, para configurar a garantia fiduciária, e atribuía ao devedor a condição de depositário, que havia um dispositivo constitucional impedindo a prisão por dívidas... salvo no caso do depositário.

"Não haverá prisão civil por dívida, multa ou custas, salvo o caso do depositário infiel".. ${ }^{18}$.

A única maneira de conceber uma garantia forte, superior às anteriores, em que se deixasse a coisa com o devedor, era colocando êste na posição de depositário.

E o estado de depositário do devedor é absolutamente exato. É mais depositário ainda - se se nos permitir do que o depositário dum contrato voluntário de depósito; porque o devedor da alienação fiduciária é depositário, não por vontade dêle, mas por vontade da lei: "ex vi legis". Além disso, o depositário é o devedor, na subjacente relação de mútuo, enquanto que no depósito comum não tem esta obrigação a mais.

Lembre-se que as obras do legislador são mais verdadeiras, na ordem jurídica em que se inserem, do que as realidades da vida privada cotidiana. Quando êle equipara o devedor ao depositário, não cabem interpretações lassas.

8. "No caso de inadimplemento da obrigação garantida, o proprietário pode vender a coisa a terceiros e aplicar o preço da venda no pagamento do seu crédito e das

16. Art. 1.266 do Código Civil.

17. Art. 1.287 do Código Civil.

18. Art. $150, \S 17 \mathrm{da}$ "Constituição do Brasil" 
despesas decorrentes da cobrança, entregando ao devedor o saldo porventura apurado, se houver", ${ }^{19}$

Eis aí a circunstância - o inadimplemento - que atualiza a faculdade de vender do proprietário. É uma faculdade que the assiste e que conseqüentemente realiza sem outras considerações. Não necessita de nenhuma autorização especial. Quando se fala de "excussão" da alienação fiduciária, usa-se dêsse têrmo em sentido lato, tomando-o da garantia do penhor. Em sentido estrito não se trata de "excussão" de coisa alheia, mas de venda duma coisa própria - o que é um direito de todo proprietário a respeito do objeto de seu domínio; direito êsse que, perante o inadimplemento, se atualizou no proprietário-fiduciário.

Todavia, poderão surgir dificuldades de tôda classe na ocasião da venda: não encontrar comprador, perante as dificuldades que possam surgir a respeito do acesso pacífico à coisa; ou ainda, a inexistência do objeto alienado em garantia; o estado em poder de terceiro adquirente; a oposição do devedor à entrega; etc.

Pode ser que o proprietário fiduciário consiga transferir a coisa a um terceiro, e que o nôvo adquirente tenha dificuldades para havê-la do devedor. De qualquer maneira, também nesta hipótese, o problema se repete, porque o devedor-depositário se nega a entregar a coisa ou o terceiro comprador não consegue havê-la.

O problema dá a medida da solução processual: Perante os problemas mais prementes ou lesões mais iniquas do direito alheio o processo responde com as ações executórias. Inclusive, freqüentemente, a fase cognoscitiva do processo é dispensada, nesses casos, entrando repentinamente, na fase executória.

Parece natural que o credor fiduciário tenha, conseqüentemente com isso, uma proteção executória. O proprietário fiduciário agora necessita da materialidade da coisa, para poder vendê-la e ressarcir-se.

19. Art. 66 , $\S 5 .^{\circ}$, da Lei 4.728 , de 14.7 .65 . 
O credor proprietário tem ação a fim de reivindicá-la do devedor ou de terceiro que a tiver. "Res pro domino suo clamat".

O têrmo reivindicação é um têrmo genérico, também usado no art. 66 da Lei de Mercado de Capitais, quando se refere com absoluta precisão técnica aos proprietários ${ }^{20}$. "O proprietário-fiduciário, ou aquêle que comprar a coisa, poderá reivindicá-la do devedor ou de terceiros, no caso de "inadimplemento"

Muito têm-se movimentado os advogados das Companhias de Financiamento e as Associações delas, no sentido de obter, e até os propuzeram, projetos processuais para os problemas que têm surgido, com a alienação fiduciária. Embora sempre possa haver legislação especial, os caminhos processuais para os casos que aparecem já estão tracados nas leis existentes.

O instituto, como tal, é nôvo, mas o legislador, como é lógico, inseriu-o no direito vigente, de maneira que nêle se encontram já as soluções processuais para os problemas que possam surgir. Independentemente, como é natural, de que possa vir a criar-se o direito adjetivo concomitante.

Segundo a nossa análise, dentre as ações vigentes, o credor-proprietário por aquisição fiduciária em garantia, poderá usar as seguintes:

20. O direito romano defendia a propriedade com a "revindicatio" o proprietário, não o possuidor, reivindica. Este tem os interditos a seu favor. À reivindicação do proprietário nada tem a ver com as reivindicações do possuidor. Em nosso direito a ação reivindicatória, concedida ao proprietário para reaver a coisa do injusto possuidor (art. 524 do Cód. Civil) decorre do "jus in re".

Não se esqueça que o credor fiduciário é proprietário. A posse do devedor, não saldando a dívida, torna-se injusta. Temos assim, caracterizada a posição das partes: o legítimo proprietário versus o possuidor precário.

No art. 647, "in fine", diz-se: “o proprietário. pode reivindicar a coisa do poder de quem a detenha".

21. Art. $66, \S 8 .^{\circ}$ da Lei 4.728 , de 14.7.65. 
1. ) a ação ordinária reivindicatória;

2..$^{\circ}$ a ação de depósito - parecendo a mais eficaz;

$\left.3 .^{\circ}\right)$ a ação de imissão na posse; logia";

4..$^{\circ}$ a ação do reservante do dominio - "ex ana-

5. ${ }^{\circ}$ cabe também a busca e apreensão, como medida preventiva em qualquer momento do processo.

9. “A ação de depósito tem por fim a restituição de objeto depositado e poderá ser exercida contra o depositário ou pessoa que lhe seja por lei equiparada"22. Já vimos acima que o devedor é depositário por equiparação legal.

"O autor na petição inicial, instruída com o documento de depósito" - no caso instruída com o contrato de alienação fíduciária, em que constam os sinais e detalhes que identificam o objeto depositado - "requererá a citação do réu para entregar, no prazo de quarenta e oito (48) horas, sob pena de prisão o objeto depositado ou seu equivalente em dinheiro, declarado no titulo ou estimado pelo autor"23.

$O$ autor equitativamente deverá declarar o saldo que lhe deve o depositário.

"Se o réu, nas quarenta e oito (48) horas seguintes à citação, não entregar ou não consignar o objeto depositado ou seu equivalente em dinheiro, o juiz expedirá mandado de prisão contra o depositário infiel, se o autor o requerer"24.

Esta ação especial, pelo seu caráter sumário é a que condiz a uma garantia como a alienação fiduciária, em que fôda a segurança descansa precisamente sôbre a proteção judiciária. O credor-depositante não tem outras armas, de maneira que abrandando a defesa do mesmo. a garantia tornar-se-á pràticamente inservível.

22. Art. 366, do Código de Processo Civil.

23. Art. 367, do Código de Processo Civil.

24. Art. 369, do Código de Processo Civil. 
Nảo se esqueça que o credor emprestou determinada importância ao devedor; eventualmente, comprou a expensas dêle o objeto depositado - como acontece em grande escala dos financiamentos ao consumidor final. Hoje, o país tem quatro bilhões e meio, aproximadamente, de cruzeiros novos emprestados sob a garantia da alienação fiduciária. Parece natural que o devedor tenha que devolver a coisa, pagar o que deve, ou pelo menos, depositá-la em juízo, como exige a ação de depósito.

10. Não se pode perder de vista a noção de posse adotada em nossa doutrina jurídica, noção essa de base germânica, fundamentada na chamada "teoria objetiva", que considera posse a tenência fática da coisa.

Chamamos a atenção para êste fato, porque embora a noção de posse seja um dos temas mais movediços da doutrina jurídica, - pense-se nas teorias histórico-jurídicas de Savigny e de Ihering - e, portanto, suscetível de considerações e reconsiderações, não há dúvida de que a orientação brasileira tende à teoria objetiva. "Considera-se possuidor todo aquêle que tem de fato o exercício, pleno ou não, de algum dos poderes inerentes ao domínio ou propriedade" (art. 485 do C.C.).

Poderes inerentes à propriedade são o gôzo ou desfrute da coisa, a tenência material dela e a livre disposição. Quem tiver algum dêsses poderes, embora não de uma maneira plena, será possuidor, à efeitos jurídicos.

O nosso devedor-fiduciante, sem dúvida alguma, é um possuidor, mas não acontece o mesmo com o credor fiduciário. Já foi amplamente visto acima, que o fiduciário adquire a titularidade da propriedade e que, não obtem posse de espécie alguma, nem sequer indireta. Desta colocação doutrinária decorre a impossibilidade de defendermos o proprietário com as ações possessórias da manutenção e de recuperação ou reintegração.

Com efeito, os interditos "recuperandae" e "retinendae" visam proteger o possuidor. 0 proprietário fiduciário nunca foi possuidor. 
O interdito de reintegração da posse visa devolver a posse da coisa a quem foi turbado na sua tenência fática dela. O interdito de manutenção protege a continuidade na posse. Em nenhuma destas duas situações se encontra o credor-fiduciário que - repetimos - nem teve, nem tem a posse. Sòmente a terá passageiramente para poder vender, e saldar a dívida.

$\mathrm{O}$ art. 371, do C.P.C., aliás é claro a respeito, exigindo desde logo, que o autor dessas ações prove, em primeiro lugar, a sua posse. O proprietário fiduciário nunca foi possuidor, e jamais portanto poderá provar a condição de possuidor. Apenas tem a titularidade do domínio, sem posse.

Existe, no entanto, outra possessória, a imissão na posse, que não exige a posse anterior do autor. É a ação especial da imissão na posse, que compete: "Aos adquirentes de bens, para haverem a respectiva posse, contra os alienantes ou terceiros, que os detenham" (art. 381, item I do C.P.C.).

Não resta dúvida de que o credor que adquiriu a propriedade, mediante aquisição fiduciária em garantia, pode defender o seu direito de proprietário mediante esta ação.

Em primeiro lugar convem reparar que a ação de imissão - que provém do latim "inmittere", "mittere in", que significa enviar a, introduzir-se em, ocupar, alcançar,

- é própria de aquêles que precisam obter ou atingir a posse; do proprietário que tem de ser introduzido no bem adquirido. Estamos então perante adquirentes de coisas que devem completar a aquisição efetuada, adquirindo a posse dos bens.

Faz sentido falar, portanto, de imissão na posse, a respeito de quem tenha direito à posse - como é o caso do proprietário da alienação fiduciária, perante a inadimplência do alienante, quando precisa da coisa para vendê-la e o devedor-alienante se nega a entregá-la.

O resultado desta ação, caso o autor ou adquirente seja favorecido, é a ordem, "missio in possessionem", por parte do juiz de imissão na posse. 
11. As diferenças entre o instituto da alienação fiduciária e a reserva de domínio são claras. A primeira se estabelece entre duas partes (que são ordinàriamente comprador e financiador), alienando uma delas em favor da outra a propriedade. A segunda figura jurídica se coloca sempre na compra-venda a prazo, a serviço do vendedor que não aliena a propriedade ao comprador, antes ao contrário a reserva com êle, até o recebimento da última prestação.

Deixando de lado outras diferenças, principalmente de função duma e outra forma de garantia no comércio, interessa destacar as semelhanças, para com base nelas, tirar alguma conclusão processual. As semelhanças são as seguintes:

1. ${ }^{\circ}$ Em ambos institutos a obrigação do devedor está representada por títulos (notas promissórias ou duplicatas). coisa.

2. ${ }^{\circ}$ Em ambos institutos o credor é proprietário da

3. ${ }^{\circ}$ Em ambos institutos existe um devedor em poder do qual está a coisa, que é do credor.

$4^{\circ}$ ) Em ambos institutos a coisa, perante o inadimplemento, garante o credor-proprietário.

Estas semelhanças permitiriam "ex analogia" atribuir :ao proprietário fiduciário a ação especial que cabe ao vendedor que se reservou o domínio. Referindo-nos a ação do Título VIII, do Código de Processo Civil.

Êsse processo é um misto de ação de cobrança do crédito quirografário (os títulos representativos do crédito) e de recuperação do objeto.

"Nas vendas a crédito de coisa móvel, com a cláusula de reserva de domínio, o vendedor poderá, por meio da ação que competir ao título de crédito, exigir o pagamento das prestações vencidas e vincendas.

$\S 1 .^{\circ}$ - Se a ação competente se iniciar pela penhora da coisa vendida, qualquer das partes poderá requerer, no curso do processo, a venda imediata em leilão"25.

25. Art. 343, do Código de Processo Civil. 
Como se pode notar a penhora do objeto é facultativa nesta ação. Trata-se duma ação que pode emprestar "servatis servandis" valioso subsídio à nova ação especial da alienação fiduciária em garantia.

No artigo dispõe-se: "Em caso de mora de pagamento imputável ao comprador e, desde logo, provada com o fítulo e respectivo instrumento de protesto, o vendedor poderá requerer prèviamente a apreensão e depósito judicial da coisa vendida, independentemente de audiência do comprador.

$\S 2 .^{\circ}$ - Feito o depósito, o comprador será citado para, em cinco (5) dias, oferecer a defesa.

$\S 30^{\circ}$ - Nesse prazo, o comprador, que houver pago mais de quarenta por cento $(40 \%)$ do preço, poderá requerer ao juiz que lhe conceda trinta (30) dias para reaver a coisa, mediante pagamento das prestações vencidas, juros e custas.

$\S 4 .^{\circ}$ - Se o réu não contestar, ou não pedir a concessão do prazo referido no parágrafo anterior, ou se o prazo decorrer sem que seja feito o pagamento, o autor poderá requerer, mediante apresentação dos títulos vencidos e vincendos, a reintegração ${ }^{26}$ imediata na posse da coisa imediata.

$\S 5 .^{\circ}$ - Se contestada, seguirá a ação o curso ordinário, sem prejuízo da reintegração preliminar."27

Em resumo, trata-se dum meio processual que, a falta de outro melhor, pode também ser utilizado, sempre e quando o nosso judiciário transigisse em extender ao credor-adquirente da alienação fiduciária esta ação, especialmente criada para o credor reservante de domínio.

26. No caso do vendedor com reserva de domínio procede a reintegração, porque o vendedor já possuiu a coisa. No caso do proprietário que adquiriu a propriedade meramente titular, sem posse, procederia a imissão na posse - porque nunca antes foi possuidor da coisa.

27 Art. 344, do Código de Processo Civil. 


\section{Conclusões}

Como em outras ocasiões, encontramo-nos perante um direito, - agora dum credor-proprietário - que pode ser defendido com várias ações, não apenas com uma. Estamos perante um verdadeiro concurso informal de ações; sendo possível ainda que o direito daquêle credor venha a ser protegido por uma ação especial: a ação do credor proprietário fiduciário.

Contudo, essa ação especial - que possa vir a ser criada, não anulará o direito do credor-proprietário a defender o seu direito em juízo com as demais ações - de maneira semelhante ao proprietário de reserva de domínio, por exemplo, que quando contou com ação especial (art. 343 e 344, do Código de Processo Civil), nem por isso perdeu o direito a outras ações: ordinária, reivindicatória, reintegração da posse, etc. etc.

Isto, não obstante, não resta dúvida de que a ação especial que venha a criar-se, em favor do credor-proprietário, será de tal maneira a êle conveniente e adatada, que provàvelmente cairão pràticamente em desuso as demais ações reipersecutórias de seu direito. A ação especial deverá respeitar o direito substantivo e servi-lo em tôda a sua complexidade. O credor-proprietário é credor quirografário, como resultado do empréstimo, e é proprietário pela aquisição fiduciária do bem móvel do devedor $O$ credor-proprietário, finalmente tem direito a venda, em caso de inadimplência do devedor e êste, o devedor, é depositário.

Disto resulta que a ação que, por ventura, venha a ser criada, deverá ser mista - porque complexa é a alienação fiduciária - para poder incluir em seu bojo, êsse conjunto de situações: a cobrança dos títulos, a apreensão da coisa, a venda da coisa para pagamento e a sanção do depositário, quando infiel.

O ponto nevrálgico, característico da nova ação, deverá girar a volta do objeto-garantia: o reconhecimento expli- 
cito do autor, como proprietário; a apreensão da coisa; a venda livre dela e a liquidação da dívida pendente. Não caracterizar isto, equivaleria a não caracterizar a ação especial da alienação fiduciária.

Apreendida a coisa proceder-se-á à venda sumária, sem cercear o direito do credor-proprietário à livre disposição, nesse momento. Os leilões judiciais poderão ser o instrumento para a venda, mas não entrave. Ainda o devedor, quando demandado, se não saldar a dívida nem entregar a coisa, deverá ser sancionado com prisão - já que o legislador quis criar uma garantia forte, baseada no depósito.

Não se poderia reduzir judiciàriamente o instituto a uma simples dívida quirografária, à cobrança; nem se poderia reduzir à reserva de domínio - na qual o comprador não tem as responsabilidades do depositário. Tampouco pode-se reduzir a interesses possessórios. Dissemos que não se pode reduzir, embora a alienação fiduciária participe, mais ou menos diretamente, dessas situações tôdas. $O$ instituto tem uma caracterização própria, um direito material singular. 